\title{
Mongolian democracy: key challenges and opportunities in modern environment
}

\author{
Khatanbold Oidov ${ }^{1, *}$ \\ ${ }^{1}$ Institute of Philosophy, Academy of Sciences of Mongolia, Ulaanbaatar, Mongolia
}

\begin{abstract}
In the last three decades, views about democracy in Mongolia have transformed from high expectations and hopes to perceived failure in performances in political and economic terms. A national and international researchers concluded that at the initial stage of democratization, Mongolians were guided by the general concepts and values of democracy such as human rights, liberty, and freedom of association and expression. Later, these values shifted to more in-depth notions that can be summarized as "democracy is a process for ensuring accountability and justice based on the active engagement of citizens". This article explores the factors that contributed to democratic challenges and bottlenecks drawing on experts' interviews conducted by the author and a review of various public opinion surveys assessing democratic performance in Mongolia. The article uses methodologies and tools designed by International IDEA and assesses the applicability of different democratic models to the Mongolian context. It argues that the evaluation of democracy in Mongolia should use additional criteria reflecting Mongolian characteristics. It concludes by suggesting that the enhancement of the democratic mechanism of accountability of public institutions is a key opportunity to consolidate democracy. The experts participating in the assessment viewed the frameworks of executive, pluralist and protective democracy are more suitable for democracy development in Mongolia, and communitarian democracy.
\end{abstract}

\section{Introduction}

Mongolia is widely considered as an "exceptionally unusual" example of democracy among the countries affected by the fourth wave of democracy in Central Asia. The country had no previous experience with Western-style democracy, even it had some unique cultural factors necessary for democracy, such as a strong desire for freedom linked to the traditional nomadic lifestyle and a preference for close connections with people from their native land. It is noteworthy that Mongolia is sandwiched between two neighbours, China and Russia, whose regimes are somewhat different from Western countries and, possibly, as Paula L. W Sabloff noticed Mongolians' sense of independence was expressed through support for democratic values [1].

Thirty years after the democratic transition, Mongolia has conducted seven parliamentary elections, six presidential elections and six elections of local self-governing institutions in

\footnotetext{
* Corresponding author: tanagar1303@mail.ru
} 
compliance with international standards of democracy. Mongolia's constitution by the People's Great Khural, which was adopted in 1992, proclaims its overall goal as "Developing humanitarian and civil democratic society" in order to ensure that people of Mongolia exercise state power using "democracy" to its largest possible extent and content. Theoretically, the constitution is grounded in classic and liberal democracy, including major values of modern democracy, such as equality, the rule of law, constitutional political government, justice, the respect for private property and the protection of fundamental rights, which guarantees freedom of speech.

However, since 2000s, hopes and enthusiasm about democracy have been tempered by concerns about the decline of the country's political and economic performance, in terms of both popular perception and democratic institutional development. Threats to democracy, including natural resource abundance, the lack of accountability, the rise in patriotic ideologies and the incompetence of political parties, have been increasing during this period. The abundance of mineral deposits provided avenues for a narrow political-business interest group to concentrate power and wealth while adopting patriotic ideologies and using democracy as a tool to protect its illegitimate acts in the name of "rapidly translating the country's natural resources into economic growth and development". There is also a perception that from the second half of 1990s to the general elections in 2004, the maturity of the political parties has appeared to slow down. Political parties were organized around small factions rather than ideology, and practices of post-trafficking, corruption and conspiracy became widespread, presenting challenges to democratization process.

\section{Materials and methods}

Section one of this article presents an overview of assessment of barriers and factors restricting democracy development, democracy's impact on the country's development and the quality of governance as reported by citizens and experts. It also compares the responses provided to a set of evaluation questions about democracy. Perceptions of citizens regarding democracy as well as the realistic expression of democracy such as institutions, their relationships and mechanisms of direct democracy were analysed based on a review of standing surveys.

Section two of this study assesses to what extent the fundamental principles of democracy have been reflected in Mongolian democracy and which features define the Mongolian democratic model. The study finds that in the first decade of democratization, Mongolians understood democracy through the principles of "human rights, freedom, freedom of expression and right to association", whereas this understanding later transformed into an "effective process for accountability which guarantees fairness and integrity based on civic participation".

Expert data for this study were collected as part of the Evaluation of Mongolian Democracy Survey from a total of 40 experts in March/April 2016 in the context of the author's Ph.D. research. General scientific-cognitive methods such as analysis-synthesis, case analysis and cluster analysis of indicators and variables such as age, gender, rural and urban and education were used when analysing the data. One of the main criteria for selecting the experts was their knowledge and experience of the country context.

The theoretical framework of this study is based on a review of modern theoretical concepts of popular rule proposed by Robert A. Dahl, Larry Diamond and Francis Fukuyama, as well as the concept of "forms of democracy that realistically exist" proposed by R. Buechi [2]; using those concepts, the author expanded the assessment's theoretical and methodological framework by adding logical matrix to the theory of democracy. The study compared four main democracy assessment methodologies, namely those developed by International IDEA (2001), USAID [3], UNDP (2011) and the World Bank (2007). The study 
mainly relied on International IDEA's State of Democracy assessment methodology because of its comprehensiveness and its focus on democracy performance, as well as its broad geographic coverage which allows comparative analysis and its credibility and validation as the methodology used by major development organizations.

The concluding section of the study argues that democracy in Mongolia is dominated by negative attitudes rather than positive ones, and key challenges are directly dependent on the slow growth of political parties, the weak understanding of politicians and citizens regarding democracy, the lack of skills and low levels of political culture. The study also offers possibilities of enhancing the methodology of democracy assessment internationally applied with additional criteria based on Mongolian characteristics.

\section{Results}

Overall assessment of the quality of democracy in Mongolia: Of the period of democracy development in Mongolia over the last three decades, the 1990s presented the period with the strongest commitment to the fundamental values and core principles of democracy. The major challenges in the development of democracy during this period were the persisting values and methods derived from the communist period and an early stage of development of the democracy mindset. However, starting in the 2000s, democratic development started to slow down and the key challenges became the general understanding that "politics and money are two sides of the same coin", meaning that politicians take power through elections, and if they succeed, use power for their personal interest while giving the impression of following democratic values.

The author asked experts to evaluate Mongolia's democratic progress. As Table 1 shows, 56.3 percent considered that democracy developed rapidly in 1990-1992; however, they considered that the democratic consolidation process started receding in the 2000s and that democracy has been moving backwards since 2008.

Table 1. Experts' evaluation on the development of Mongolian democracy (percentage).

\begin{tabular}{|c|c|c|c|c|c|}
\hline Years & $\begin{array}{c}\text { Intensive } \\
\text { growth }\end{array}$ & $\begin{array}{c}\text { Growth in } \\
\text { general }\end{array}$ & Stagnated & $\begin{array}{c}\text { Partly } \\
\text { regressed }\end{array}$ & $\begin{array}{c}\text { Regressed in } \\
\text { general }\end{array}$ \\
\hline $1990-1992$ & 56.3 & 34.4 & 3.1 & 3.1 & 3.1 \\
\hline $1992-1996$ & 18.8 & 46.9 & 12.5 & 18.8 & 3.1 \\
\hline $1996-2000$ & 6.3 & 50.0 & 28.1 & 9.4 & 6.3 \\
\hline $2000-2004$ & 3.1 & 31.3 & 28.1 & 25.0 & 12.5 \\
\hline $2004-2008$ & 0.0 & 43.8 & 18.8 & 18.8 & 18.8 \\
\hline $2008-2012$ & 6.3 & 40.6 & 6.3 & 18.8 & 28.1 \\
\hline $2012-$-Present & 0.0 & 21.9 & 6.3 & 21.9 & 46.9 \\
\hline
\end{tabular}

This situation is consistent with findings from other surveys. For example, the Asian Barometer Survey conducted in 2006 [4] found that the proportion of the respondents who supported democracy "realistically" in Mongolia - 30 percent - was lower than regional average of 35 percent in Eastern Asia and 38 percent in Eastern Europe. According to Mongolian political scientist D. Ganbat, Mongolians were "fully supportive to democratic ideals, have low levels of understanding on democracy, only a minority of the population support democracy realistically and citizens have low levels of need (demand) to strive for democracy" [5]. Citizens' expectations that were created during the early stages of democracy become challenged due to realistic processes of Mongolian democracy development.

Therefore, it is important to examine why democracy started declining and moving backwards according to citizens' views. Survey results from different years on the three main 
indicators - level of satisfaction, support and trust of democracy - determining citizens' understanding and perceptions of democracy are demonstrated in Table 2.

Table 2. Barriers to the development of Mongolian democracy (percentage).

\begin{tabular}{|l|c|c|c|c|}
\hline Expressions & 2013 & 2010 & 2008 & 2005 \\
\hline $\begin{array}{l}\text { Ignorance of constitutional \& international human rights } \\
\text { principles, \& inadequate accountability system }\end{array}$ & 13.9 & 16.4 & 14 & 16.2 \\
\hline $\begin{array}{l}\text { All issues of the country \& individuals are not solved by human } \\
\text { rights-based approach; instead, money decides all }\end{array}$ & 9.6 & 7.3 & 16.4 & 17.8 \\
\hline Corruption not declining & 9.3 & 16 & 15 & 18.8 \\
\hline Citizens' political and civil rights are limited & 7.2 & 10.3 & 10.3 & 13.6 \\
\hline Lack of democracy education & 7 & 2.4 & 2.4 & 0.7 \\
\hline Dependency of public service on politics & 12.4 & 10.6 & 22.8 & 14.2 \\
\hline Slow process of legal reforms & 21.8 & 25.1 & 20.6 & 20.4 \\
\hline Unskilled political officials & 3.1 & 13.8 & 14.1 & 19.7 \\
\hline Party-centred system and old communist attitudes & 2.3 & 1.9 & 4 & 6.9 \\
\hline Lack of fairness and injustice & 9.4 & 10.9 & 8.2 & 7 \\
\hline Personal ambitions of politicians and political parties & 11.6 & 4.4 & 8.8 & 8.4 \\
\hline Limitations of political culture, education and knowledge & 7 & 2 & 5.1 & 12.4 \\
\hline Divide into friends and acquaintances and chaotic situation & 2.3 & 4.4 & 16.4 & 17.8 \\
\hline Lack of transparency & 2.3 & 3.1 & 3.8 & 6.2 \\
\hline Inadequate enforcement of legislation & 2.3 & 6.2 & 14 & 16.2 \\
\hline Bureaucracy & 7 & 8.1 & 6 & 8.3 \\
\hline Lack of independence of judicial sector & 2.3 & 7 & 4.2 & 1 \\
\hline Lack of freedom of information and access to information & 2.3 & 1.1 & 0.9 & 2.4 \\
\hline Unfair competition among political parties & 16 & 11.8 & 22.5 & 5.2 \\
\hline Sources: Governance Research
\end{tabular}

Sources: Governance Research Team, IPSL, UNDP, 2006, 2008, 2010; SPAI, IPSL, 2013.

As Table 2 illustrates, the four main perceived barriers to democracy development are excessive personal ambitions of political parties and politicians (15.6 percent), dependency of the public service on politics (12.4 percent) and the slow process of legal reforms (21.8 percent). Other obstacles were also mentioned, including the lack of democracy education, the lack of fairness, widespread injustice, and the limitations of political culture, education and government bureaucracy. When asked to identify underlying causes that hinder democracy, experts highlighted the lack of citizens' political education and culture and the gap between rich and poor. According to the experts' view on Democratic Governance Indicators: Assessing Democratic Governance in Mongolia, [6]. a society where citizens have democracy education and high level of political culture, politicians and their acts are restrained and democratic values are safeguarded; thus, such culture serves as a fundamental requirement for democracy. The middle class in a given society guarantees the existence of democracy, yet Mongolia's society is becoming increasingly polarized and creating the basis for many factors that impede democracy.

A comparable question about the factors restricting Mongolian democracy was asked from the experts. Seventeen factors were named with the major factor being fight for power (named by 81.3 percent of respondent-expert) followed by 'corruption and bribe' (75 percent), widespread injustice (65.6 percent), poor development level of political parties (46.9 percent), politicians' preference of their personal interests ( 37.6 percent), low education level (34.4 percent), societal chaos/mess (18.8 percent), government bureaucracy and burden (15.6 percent) and weak operations of law enforcement agencies (12.5 percent).

Interestingly, citizens' perceptions and experts' opinions on key factors impeding Mongolian democratic development overlap significantly, suggesting the above-mentioned barriers and factors negatively affect the development and quality of Mongolian democracy. Second, citizens and experts agree that these factors are complex and related to a wide variety of other processes and phenomena. 


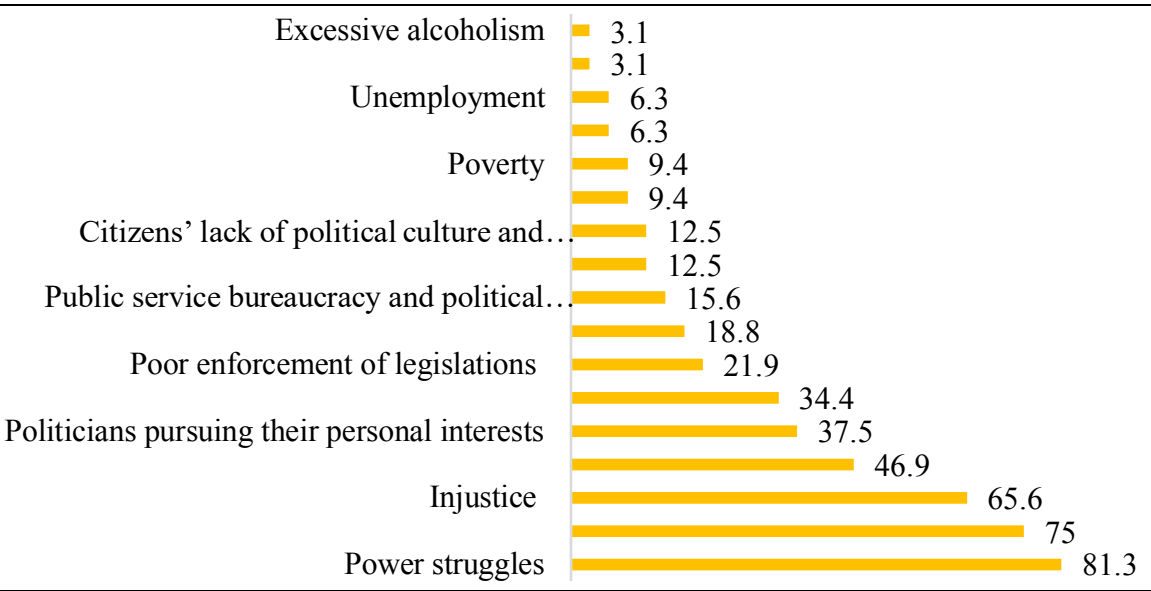

Fig. 1. Factors restricting Mongolian democracy.

Therefore, to further clarify the key factors that cause challenges to Mongolian democracy, we explore what impact democracy can have on the country and its citizens. The evaluation given by experts reveals how Mongolian democracy influences the country's development and illustrates that experts tend to cite positive influence regarding general trends: of the six indicators that were assessed, five were generally evaluated positively with more than 50 percent of scores. This explicitly demonstrates that the democracy has become a decisive factor for the country's development despite challenges to democratic development. Table 3 provides the results from the experts' assessment conducted in 2013 and 2016.

Table 3. Experts' opinion on the impact of democracy on the Mongolia's development, by percentage and year.

\begin{tabular}{|c|c|c|c|c|c|c|}
\hline $\begin{array}{l}\text { Experts' opinion on the } \\
\text { impact of democracy }\end{array}$ & Years & Positive & $\begin{array}{l}\text { Relatively } \\
\text { positive }\end{array}$ & Neutral & $\begin{array}{l}\text { Relatively } \\
\text { negative }\end{array}$ & Negative \\
\hline \multirow[t]{2}{*}{ Economic development } & 2016 & 13 & 19 & 47 & 16 & 9 \\
\hline & 2013 & 2.2 & 7.9 & 37.1 & 30.3 & 22.5 \\
\hline \multirow[t]{2}{*}{ Political development } & 2016 & 9 & 19 & 38 & 28 & 6 \\
\hline & 2013 & 4.5 & 15.9 & 29.5 & 28.4 & 21.6 \\
\hline \multirow{2}{*}{$\begin{array}{l}\text { Consolidation of the civil } \\
\text { service }\end{array}$} & 2016 & 3 & 6 & 38 & 31 & 22 \\
\hline & 2013 & 3.4 & 30.7 & 37.5 & 15.9 & 10.2 \\
\hline \multirow[t]{2}{*}{ Human development } & 2016 & 9 & 50 & 28 & - & 9 \\
\hline & 2013 & 3.4 & 8 & 39.6 & 29.5 & 19.3 \\
\hline \multirow{2}{*}{$\begin{array}{l}\text { National independent \& } \\
\text { Security }\end{array}$} & 2016 & 22 & 25 & 34 & 9 & 9 \\
\hline & 2013 & 4.5 & 16.9 & 30.3 & 27 & 20.2 \\
\hline \multirow{2}{*}{ Foreign relations } & 2016 & 34.4 & 40.6 & 18.8 & 3.1 & 3.1 \\
\hline & 2013 & 1.1 & 29.5 & 35.2 & 31.8 & 2.3 \\
\hline
\end{tabular}

Source: Governance Research Team at SPAI, IPSL, 2013

More experts considered that democracy positively impacts citizens' livelihoods and economic development in 2016 than in 2013. It is also an expression of support from stronger real democracy noted before. The dependence of citizens' livelihoods, in other words, during the democratic period on the state and politicians incrementally declined while the dependence on personal efforts and commitments has increased, albeit slowly. The sector in which democratic principles are embedded the least was the public service; among many reasons, the key one is that the presence of political influence in the public service and 
inappropriate selection processes of public servants have been making the public service weak, unstable and reduced its capacity.

Experts were asked to evaluate the extent of democratic governance in Mongolia. The responses, summarized in Figure 2, show that they considered taking responsibility as the least embedded characteristics with nearly 71.9 percent saying it is "very poor", followed by accountability (46.9 percent "poor" (46.9), "very poor" (28.1), fair operations as considered by "very poor" (40.6 percent) and enforcement of law and rule of law ("poor" (37.5 percent) and "very poor" (28.1 percent). Several characteristics of democratic governance were evaluated as "fair", such as openness and transparency (50 percent) and citizens' participation (50 percent). This suggests that experts believe that some key characteristics for democratic governance have not been fully established, the democracy strengthening process has slowed down, and some backwards moves are observed. The expert assessments and citizens' perceptions survey on the characteristics of democratic governance had some overlap; for instance, views that the fundamental principles of justice, accountability, fair judicial sector and rule of law are not fully implemented and these pose great challenges to society were common in both types of surveys.

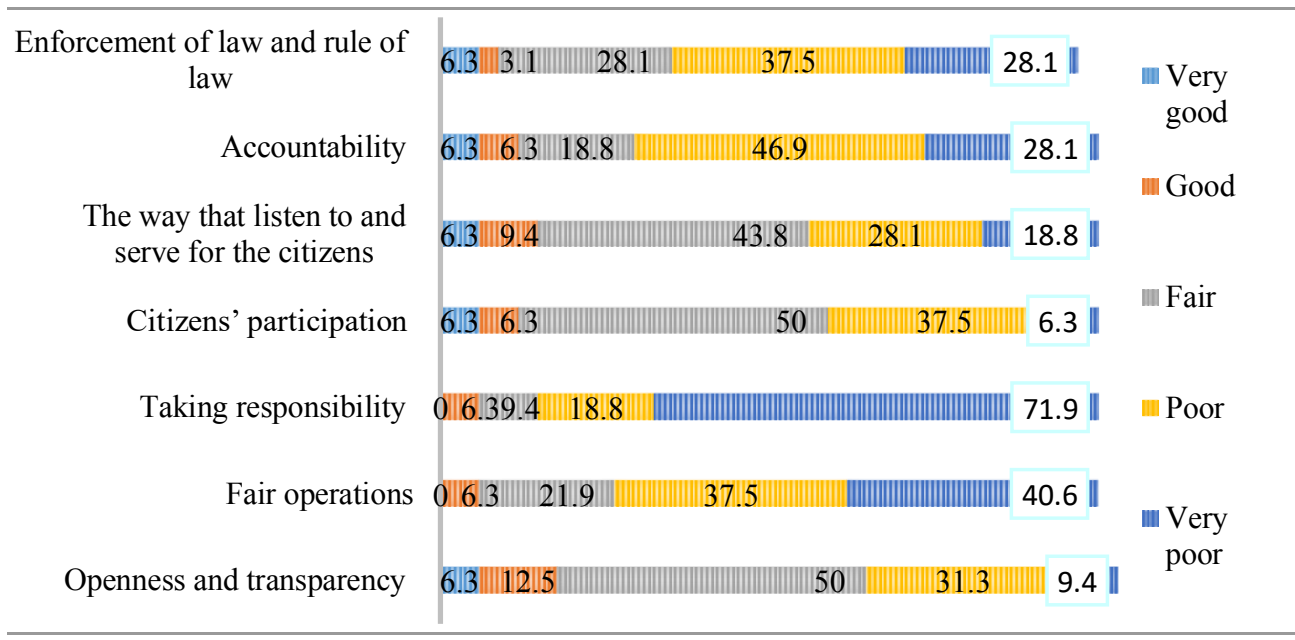

Fig. 2. Experts' evaluation of key characteristics of Mongolia's democratic governance, Note: Percentage of respondents in the expert survey done within the framework.

Finally, characteristics of democratic governance can be assessed by the degree of citizens' trust in key democratic institutions and how citizens evaluate the performance of these institutions. Almost all studies conducted in Mongolia draw a similar picture. The Democratic Governance Survey made by the National Statistics Office evaluates the pace of democracy development in the key institutions, including the President's Office, Parliament, Cabinet and local governments, covering much wider scope using credible sampling with frequent intervals. According to the 2018 survey findings, citizens assessed the performance of the president at 44 percent (out of 100), the Executive Government at 22 percent and the Parliament at 13 percent. It is noteworthy that overall picture of citizens' evaluation on the key institutions of the governance system remained stable for a number of years.

\section{Discussion}

Searching for an appropriate model for Mongolian democracy: Democratization in Mongolia created societal groups that differ from each other by views, interests and forms of contribution towards the country's development. The process laid the foundation for many 
important occurrences. Mongolians have begun an important process of political action in accordance with their ideologies and beliefs, as well as the formation of a new multi-party system. Therefore, the majority of conversations, discourse and research on democracy held in Mongolia take place under the overall conceptual framework of "Mongolian democracy". People and political circles and researchers account for the majority of supporters of this concept. In the 20th century, Mongolians started studying, writing and speaking about democracy. The discussion was initially guided by "proletarian or socialist democracy", as part of Marxist theory, then it was shaped by "liberal democratic" theory. Attempts to introduce socialist democracy were unsuccessful by mid-1990 and were followed by more than 20 years of attempting to mainstream liberal democracy. Still, this process is slowing down and even going backwards over the decade or more. There is a need to develop an appropriate model for democracy in the Mongolian context and to focus on the methodology for this search.

Scholars have undertaken numerous studies on the quality, forms and models of democracy, as well as its impact on development. Many scholars, including Dahl, Durkheim, Parsons, Inglehart, Popper, Lintz, Lipset, Huntington, Fukuyama, Diamond, Collier and Levitsky, have contributed to the development of democratic theory. Despite the obvious fact that these studies focus on different dimensions and are based on varying rationales, theories and research on democracy have a lot of directions were born resulting in a "theoretical chaos" [7]. Political systems, governance structures and social practices of democracies in different countries are determined by diverse national historic, cultural, social and economic factors and have led to a range of models. As a result, according to M.Tommasoli, it is not possible to develop a single notion of how democracy must function [8].

A logical matrix methodology consisting of expressions of democratic theories was developed to identify the most suitable model of democracy, and the questionnaire for experts was used to assess different expressions of democratic theories. The logical matrix consists of seven classifications: pre-modern democratic theory, liberalism and republicanism, republicanism and communitarian thinking framework, modern democratic theory framework, pluralist democracy ideological framework, executive democracy ideological framework and participatory democracy concepts.

The pre-modern framework of democratic theory clarifies the relations between our understanding, the approach, concepts and principles of democracy that we call as "classical", which is renewed within the modern democracy theoretical systems. This framework must couple the rights, liberty and equality principles with the rule of law and people's power in order to prioritize the connections with societal justice, as evidenced by the responses given by experts. Figure 3 demonstrates that, according to experts, unlimited freedom lays the foundation for dictatorship, polarization and deprivation of democratic principles (81.3 percent), destroys the rule of law if the wider participation of the middle class is not ensured (78.1 percent) and degrades justice (62.6 percent). In other words, ideas that were developed by thinkers of classical democracy, including Pericles, Socrates, Plato and Aristotle, remain valid. This was assessed by experts and fully suits Mongolia's democratic development, as 69.5 percent of experts agree with the main characteristics of the pre-modern theoretical framework.

The pillar of liberal ideology is liberty, which serves as the core value for all humankind. However, its concepts and doctrines were developed on a Western societal foundation, increasingly thought to be solely Western phenomena. Figure 4 summarizes the expert assessment results on the suitability of liberalism and republicanism for the Mongolian context. Experts thought that core principles of democracy have been eroded not because of "loss of democratic equality concept but because of misallocation of political power in the hands of few" (93.7 percent). The experts fully agreed (90.7 percent) that democracy provides opportunities and skills for citizens to build a healthy society and "the scope and norm for 
democracy to effectively implement are created through the development of culture and education" (84.3 percent). The concepts were developed by thinkers of modern democratic theories including John Locke, James Madison, Charles Louis Montesquieu, Alexis de Tocqueville, John Stuart Mill, and John Rawls. Experts interviewed believed that the government must base its actions upon people's will, whereas an imbalance of power in the hands of a few can result in dictatorship. The experts reiterated that democratic norms can be expanded through the promotion of democratic culture and education and that justice is an important guarantee for the existence of democratic institutions (average of 81.2 percent).

\begin{tabular}{|c|c|c|}
\hline \multirow{4}{*}{$\begin{array}{l}\square \text { Disagree Average percentage } \\
\text { In the event that participation of the middle class is ensured } \\
\text { at the maximum possible extent, its shall be the realistic }\end{array}$} & \multirow[b]{2}{*}{30.4} & \multirow[b]{2}{*}{69.5} \\
\hline & & \\
\hline & & \\
\hline & 21.9 & 78.1 \\
\hline Societal relations are based the principles of labor & & \\
\hline distribution/allocation principle and ensuring justice is & 37.4 & 62.6 \\
\hline Limitless freedom lays the foundation for dictatorship, & & \\
\hline polarization and deprivation of democratic principles & 18.7 & 81.3 \\
\hline Justice and integrity are not ensured by everyone on their & & \\
\hline own will, but everyone can cease in injustice by & 43.7 & 56.2 \\
\hline
\end{tabular}

Fig. 3. Experts' assessment of the expressions of pre-modern democratic theory and its historic theoretical frameworks (by percentage).

\begin{tabular}{|c|c|c|}
\hline \multicolumn{3}{|l|}{ Average } \\
\hline ㅁDisagree & 18.7 & 81.2 \\
\hline $\begin{array}{l}\text { The scope and norms of democracy to effectively work are } \\
\text { created through the development of culture and education. }\end{array}$ & 15.7 & 84.3 \\
\hline $\begin{array}{l}\text { It is important to create skills and conditions for citizens to } \\
\text { establish a healthy society. }\end{array}$ & 9.3 & 90.7 \\
\hline $\begin{array}{l}\text { The principle of democracy is not due to the loss of the idea } \\
\text { of equality, whereas, the distribution of power is lost, or } \\
\text { power is transferred to someone else, and it is violated by.. }\end{array}$ & 6.3 & 93.7 \\
\hline $\begin{array}{l}\text { It fully ensures basic human rights, including right to life, } \\
\text { right to property and right to employment and labor and the } \\
\text { people are governed by leaders that ensure all of these rights. }\end{array}$ & 43.8 & 56.2 \\
\hline
\end{tabular}

Fig. 4. Experts' assessment on the expressions of liberal and republican frameworks (by percentage).

Republican and communitarian thinking, when assessed, focuses on avoiding dictatorship and anarchy and on establishing a democratic republican system. Thinkers such as J.J. Rousseau [9], Jeremy Bentham [10] and Emile Durkheim [11] emphasized the need to avoid dictatorship and anarchy. The experts' responses shown in Fig. 5 indicate that the main ingredients for exercising the right to govern a society are: devoting more attention to needs of the society and people ( 84.5 percent), the state taking responsibility for making decisions compliant with public interests (71.9 percent) and the existence of a common value system based on liberty (62.5 percent). Overall, 68 percent of the experts generally agreed the key elements of republicanism and communitarianism are suitable for the Mongolian context. They further emphasized the need to turn these values into wider societal values and norms in Mongolia. 


\begin{tabular}{|c|c|c|}
\hline \multirow{2}{*}{ DDisagree } & & \\
\hline & 31.2 & 68 \\
\hline \multirow{2}{*}{$\begin{array}{l}\text { Moral unity, independent of the individual, is the basis of } \\
\text { social existence of a common value system based on liberty }\end{array}$} & & \\
\hline & 34.3 & 62.5 \\
\hline \multirow{2}{*}{$\begin{array}{c}\text { It depends on how each person respects his/her rights and } \\
\text { interests and how each person implements their skills of } \\
\text { protecting their rights, liberties and opportunities... }\end{array}$} & & \\
\hline & 46.8 & 53.2 \\
\hline \multirow{2}{*}{$\begin{array}{l}\text { The state must be responsible for the equal distribution of } \\
\text { income and address the interests and views of people in a } \\
\text { way that is equal as part of an appropriate policy. }\end{array}$} & & \\
\hline & 28.1 & 71.9 \\
\hline \multirow{2}{*}{$\begin{array}{l}\text { For the implementation of governance rights, it is important } \\
\text { penetrate the minds of the people, and pay to reign in more } \\
\text { depth to their actions }\end{array}$} & & \\
\hline & 15.5 & 84.5 \\
\hline
\end{tabular}

Fig. 5. Experts' assessment of the republican and communitarian frameworks (by percentage).

One key guarantee for protective democracy is that it argues citizens' political culture and active participations are key ingredients of democracy, creating. In other words, a political culture is a prerequisite for stable democratic development. It is commonly understood that democracy has no direct relevance to certain economics doctrines, but that economic freedom serves as the key guarantee and element of the democratic society. Figure 6 indicates that the majority of experts (84.4 percent) considered that elections are not sufficient to grant a secure life, wealth, the right to education and new opportunities for citizens, nor to guarantee democracy in Mongolia. In contrast, 75.1 percent of experts agreed that broader opportunities and powers of citizens to oversee activities of their agents, elected and authorized by citizens, are a key characteristic of modern democracy in Mongolia. Overall, only 50.8 percent of experts agreed that the values of citizen choice (e.g. Sen, Amartya [12], Sydney Verba \& Almond A.Gabriel [13], Hayek A.Friedrich [14] and the mechanism of oversight of agents representing citizens have been embedded in Mongolian democracy.

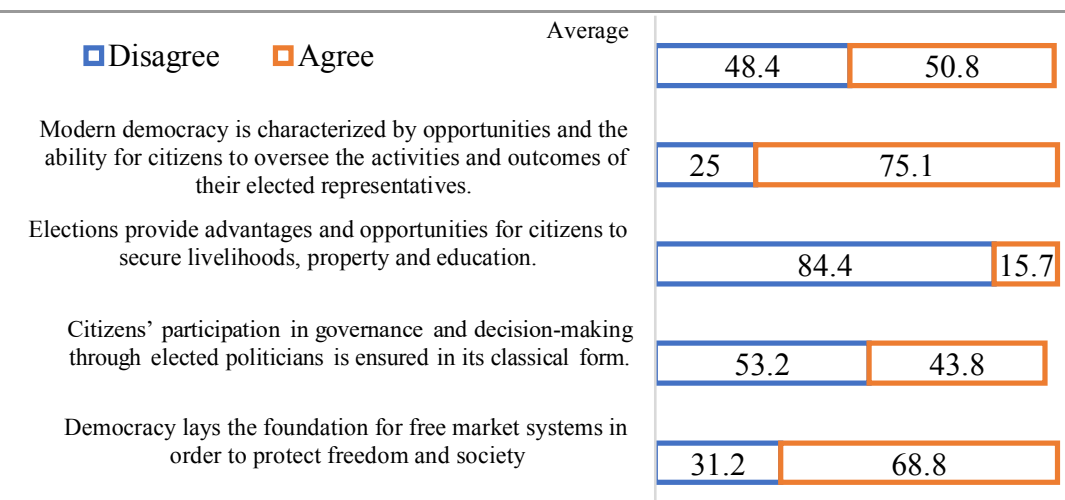

Fig. 6. Modern democracy theoretical framework: Evaluation of the expression/characteristics of protective democracy in Mongolia ( by percentage).

The most common type of democracy in the modern world is pluralist democracy, represented by scholars including Robert Dahl, David Easton, Seymour Martin Lipset, Juan Linz, Ronald Inglehart, Samuel Huntington, and David Held. Experts were asked to evaluate to what extent characteristics of a pluralist form of democracy are embedded in Mongolian democracy. In total, 72 percent agreed that democracy in Mongolia gives opportunities for recognition and ownership of democratic values and direct, constructive and active engagement of citizens in decision-making as well as proves opportunities for casting votes 
and expressing opinions in the elections and referendums (Fig. 7). Overall, 60.2 percent of experts agreed notions and values of pluralistic democracy have been mainstreamed in Mongolian democracy.

\begin{tabular}{|c|c|c|}
\hline & & \\
\hline agree $\square$ Agree & 31.1 & 60.2 \\
\hline $\begin{array}{l}\text { Democracy exists provided that the majority of people elects } \\
\text { the main political leaders through competitive elections }\end{array}$ & 18.7 & 59.4 \\
\hline $\begin{array}{l}\text { Realistic opportunities for people to express their opinion and } \\
\text { speak out when they take part in elections and referendums. }\end{array}$ & 28 & 72 \\
\hline $\begin{array}{l}\text { It reduces the human tendency to approach things from a } \\
\text { random, unexpected position. }\end{array}$ & 50 & 37.5 \\
\hline $\begin{array}{l}\text { Able to provide opportunities for citizens to have ownership } \\
\text { of democratic values and participate in the law-making }\end{array}$ & 28 & 72 \\
\hline
\end{tabular}

Fig. 7. Modern democracy theoretical framework: Evaluation of the expression/characteristics of pluralist democracy in Mongolia (percentage).

Regardless of whether democracy is new or old, countries with democratic systems often encounter a common phenomenon called by Przeworski Adam the "democracy crisis" [15]. Figure 8 indicates that there was an overwhelming agreement ( 84.4 percent) among experts that liberty and equality serve as the prerequisites and are essential for people to oversee their political leaders and implement the rule of law effectively. Furthermore, 78.1 percent of experts agreed that civil society, as a pillar for strengthening democracy and further reforms, must collaborate in solidifying the legitimacy of governance institutions and 71.9 percent indicated every citizen must exercise the right to participation in political processes and decision-making. The majority of the experts ( 72.6 percent) considered the characteristics of executive democracy are suitable for the current political situation and Mongolian cultural attitudes, and hence for Mongolian democracy.

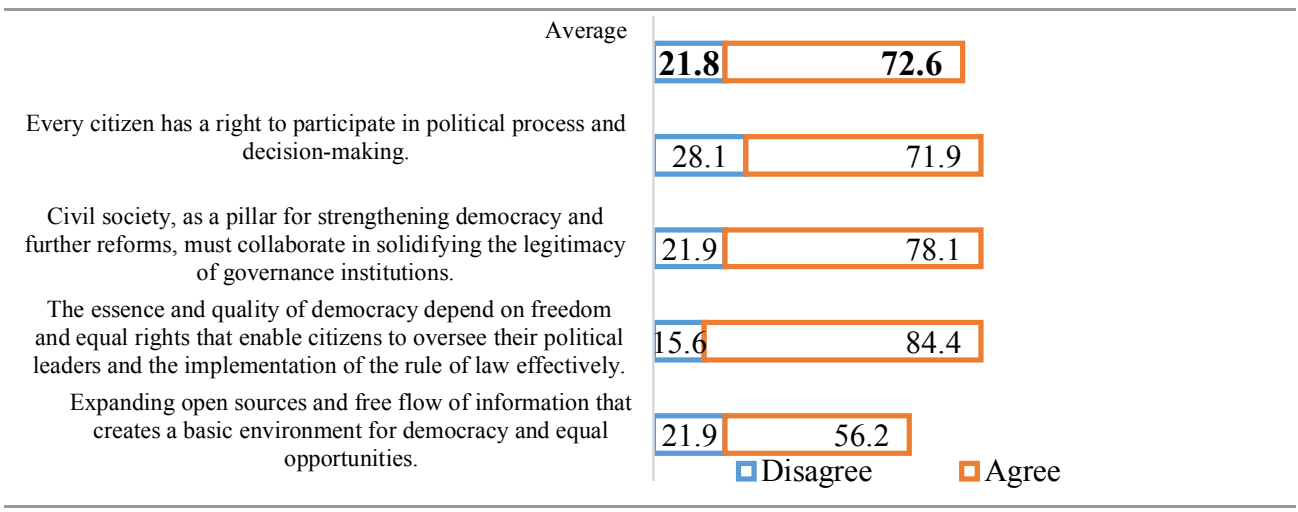

Fig. 8. Evaluation of the expression/characteristics of executive democracy in Mongolia (by percentage).

Finally, among the different forms of democracy, experts agreed on the importance of combining the elements of direct and representative democracies (90.6 percent) and highlighted the need to establish systems and encourage citizens to protect their legitimate interests in the matters of public (87.5 percent). Experts agreed that opportunities for effective participation by empowering citizens ( 65.5 percent) and opportunities for engaging with 
citizens for political agenda-setting and decision-making (79.6 percent) have been established, showing overall positive outcomes (Fig. 9).

\begin{tabular}{|c|c|c|}
\hline \multirow[b]{2}{*}{$\square$ Disagree $\square$ Agree } & & \\
\hline & 20.3 & 79.6 \\
\hline \multirow{2}{*}{$\begin{array}{l}\text { Need to establish systems and encourage citizens to protect } \\
\text { their legitimate interests in the matters of public. }\end{array}$} & & \\
\hline & 12.5 & 87.5 \\
\hline \multirow{2}{*}{$\begin{array}{l}\text { It is necessary to combine direct and representative } \\
\text { democracies. }\end{array}$} & & \\
\hline & 9.4 & 90.6 \\
\hline \multirow{2}{*}{$\begin{array}{l}\text { It is vital to create opportunities for full participation of } \\
\text { citizens by empowering them. }\end{array}$} & & \\
\hline & 34.5 & 65.5 \\
\hline \multirow{2}{*}{$\begin{array}{l}\text { Opportunities for direct engagement with citizens to develop } \\
\text { policy and decision-making must be established. }\end{array}$} & & \\
\hline & 25 & 75.1 \\
\hline
\end{tabular}

Fig. 9. Experts' assessment of the concepts of participatory democracy (by percentage).

\section{Conclusions}

When commonly accepted values of democracy are incorporated and implemented or expected in the lives and activities of people and socio-political spheres, the country can be said to broadly follow a "democratic model". This concept covers all spheres and strata, from the day-to-day lives of citizens to forms of political governance, to political process and phenomena. Good and democratic governance implies equal opportunities for citizens and that ensures social and economic balances.

- The first section of this article showed that in regard to the current status of Mongolian democracy, institutionalized structures and forms of democracy have been established structurally, yet the society is not necessarily democratized and the way that institutions operate and policies are implemented is still not democratic. A review of existing surveys highlighting citizens' attitudes towards democratic values is dominated by hesitation and generalized judgements. The public has growing concerns that democracy in Mongolia is becoming vulnerable and that the democratic development and future trends are challenged by wide variety of obstacles.

- Nonetheless, national and international researchers have concluded that at the initial stage of democratization, Mongolians were guided by the general concepts and values of democracy such as human rights, liberty, and freedom of association and expression. Later, these values shifted to more in-depth notions that can be summarized as "democracy is a process for ensuring accountability and justice based on the active engagement of citizens". This shift provides opportunities for researchers to assess the quality of democracy. Nonetheless, there remains a lack of tangible studies and conclusions that consider Mongolian democracy as an "independent model" and that assess the quality of Mongolian democracy. In addition, international assessment and evaluation tools and methodologies have not considered a separate "Mongolian model". The ideas and recommendations of this chapter aim to contribute to this discussion.

- The second section of this article attempted to assess which characteristics of democracy fit the Mongolian democratic model. The concepts of participatory democracy and expressions of liberalism and republicanism were found suitable for a Mongolian model. The experts participating in the assessment agreed that the principles of democracy are violated not due to loss of importance of the concept of equality, but due to the concentration 
of power into a single institution. In contrast, the experts viewed the frameworks of executive, pluralist and protective democracy are more suitable for democracy development in Mongolia, and communitarian democracy, and pre-modern democracy are not suitable for assessing Mongolian democracy.

- Current views about democracy in Mongolia are generally negative. The following changes need to be in place to enhance democracy in Mongolia:

$\circ \quad$ Recognize that different aspects of democratic governance have regressed and do not meet the expectations of citizens.

- Parliament's research capacity is low and needs to be strengthened to allow lawmakers to make evidence-based decisions that would help improve the quality of laws and their ability for enforcement.

- Citizens increasingly face obstacles in exercising their rights to elect and to be elected due to governance systems and legal challenges such as problems in voting sheets, unrealistic election promises and vote-buying which affect the fairness of elections and their results. Therefore, electoral democracy needs to be strengthened.

○ The development of the multiparty system and the parties has decelerated, resulting in a drastic decline of citizens' confidence in political parties. Enhancing the democratic mechanism of accountability within political parties themselves as well as public institutions is key in consolidating democracy.

- Government failed to implement appropriate and concrete policy actions for improving citizens' political education and awareness on democracy. As such, the key guarantee for democracy has not yet been adequately established.

○ Some efforts including steps towards public service reform and the renewal of the Public Service Law were undertaken by the government. However, the new law is enforced only slowly, the Public Service Council has not been reformed and is operationally weak, and the public service struggles with low capacity and weak operations.

- Civil society organizations play an important role in the development of democracy, yet they need to further develop and innovate.

\section{References}

1. P.L.W Sabloff, Does Everyone Want Democracy? Insights from Mongolia 13-15 (2013) DOI 10.1163/22105018-90000072

2. R. Buechi, Use of Deirect Democracy in the Jura Conflict, Direct Democracy and Minorities 182-184 (2014) DOI 10.1007/978-3-531-94304-6_13

3. G. Frankenberg, Comparative Constitutional Design (Ed. Ginsburg T., 2005) DOI 10.1093/icon/mot006

4. Y. Chu, L. Diamond, A. Nathan, D. Shin, How East Asians View Democracy (NEW YORK: Columbia University Press, 2008) doi:10.7312/chu-14534

5. D. Ganbat, R. Tusalem, D. Yang, The mass public and democratic politics in Mongolia, In Chu Y., Diamond L., Nathan A., \& Shin D. (Eds.), How East Asians View Democracy (NEW YORK: Columbia University Press, 2008) DOI:10.7312/chu-14534.10

6. Changes in the State of Democracy in Mongolia. 2009-2010. (2010). MDG9 Project. UNDP: Sansudai Printing.

https://www.idea.int/sites/default/files/pictures/esod book dgi iii report april30 2011.pdf

7. L. Diamond, Is the third wave over? Journal of Democracy, 20-37 (1996) DOI:18457361(199607)7:1 
8. M. Tommasoli, Representative democracy and Developing the capacity building of responsible politics (2005), available at https://www.idea.int/sites/default/files/speeches/Representative-Democracy-andCapacity-Development-for-Responsible-Politics.pdf

9. J. Benett, J.J. Rousseau, The Social Contract 39-42, ISBN 978-14-4171-466-4 (2017) https://www.earlymoderntexts.com/assets/pdfs/rousseau1762.pdf

10. J. Bowring, The Works of Jeremy Bentham, London, 1838-1843 (Reprinted New York, 1962) https://oll.libertyfund.org/title/bowring-the-works-of-jeremy-bentham-vol-1

11. E. Durkheim, The Division of Labor in Society (1933) ISBN 978-0-684-83-638-6. http://fs2.american.edu/dfagel/www/Class\%20Readings/Durkheim/Division\%200f\%2 0Labor\%20Final\%20Version.pdf

12. A. Sen, The Idea of Justice 331-342 (2009) DOI: 10.1080/14649880802236540

13. V. Sydney, A. Gabriel, The Civic Culture: Political Attitudes and Democracy in Five Nations 3-42 (1963) DOI: 10.1515/9781400874569-003

14. A.F. Hayek, The Political order of a Free People 561 (1979) DOI:10.2307/1599409

15. A. Przeworski, Crises of Democracy 15-16 (2019) DOI: $10.1017 / 9781108671019$ 